\title{
A Research on the Basis of Questionnaires about the Dental Patients' Awareness and Understanding of TMDs
}

\author{
Kyung Hee Kim, D.D.S., M.S.D., Ph.D \\ Department of Oral Medicine, Busan Paik Hospital, Inje University
}

This study was conducted to investigate and analyze the dental patients' awareness and understanding about TMDs. Among the total number of 243 patients who had visited the department of dentistry of Busan Paik Hospital, Inje University or Hanvit dental hospital in Ulsan metropolitan city and participated in the survey, 195 patients who filled in all parts of the questionnaire were selected as the subjects. The results were as follows.

1. The subjects who were aware of the term, "TMDs" were $17.4 \%$. The group with total education period of 12 years and over was significantly more aware of "TMD" $(82.4 \%, \mathrm{p}<0.01)$ than the other group. The subjects who were aware of the term, "jaw joint disease" were $81.0 \% .30$ to 49 age group $(45.6 \%, \mathrm{p}<0.05)$ and the group with total education period of 12 years and over $(60.1 \%, \mathrm{p}<0.01)$ were significantly more aware of "jaw joint disease" than other groups.

2. More than half of the subjects chose "overuse of the jaws" as the concept of jaw joint disease $(50.6 \%)$.

3. $\mathrm{TV}$, radio $(41.4 \%)$ was the most frequent source of awareness about jaw joint disease followed by family and friends(20.2\%), hospitals and health professionals(18.2\%), internet(15.7\%) and newspapers, magazines(4.5\%). Among the respondents who were aware of jaw joint disease through $\mathrm{TV}$, radio, 30 to 49 age group showed significantly higher percentage $(52.4 \%, \mathrm{p}<0.05)$ than other age groups. Among the respondents who were aware of jaw joint disease through internet, 18 to 29 age group showed significantly higher percentage $(61.3 \%, \mathrm{p}<0.01)$ than other age groups. Among the respondents who were aware of jaw joint disease from hospitals and health professionals, the group with total education period of 12 years and over showed significantly higher percentage $(75.0 \%, \mathrm{p}<0.05)$ than the other group.

4. Noise during mouth opening and closing $(26.9 \%)$, mouth opening difficulty(25.1\%) and jaw pain(13.7\%) were the most frequently responded sign and symptoms of jaw joint disease. For the causes of jaw joint disease, enjoying hard food chewing(19.5\%), occlusal discrepancy(19.0\%) and chewing with one side only(18.5\%) were responded in sequence. TMJ surgery (28\%) was the most frequently responded treatment method for jaw joint disease, followed by occlusal appliance therapy (23.9\%) and physical therapy(14.6\%). For preventive method of jaw joint disease, avoid eating hard food(21.1\%), avoid opening mouth wide(17.0\%) and simultaneous using of molar of both side when chewing food(15.4\%) were chosen frequently.

Key words : Awareness, Understanding, Jaw joint disease, Questionnaire, Temporomandibular disorders(TMDs)

\author{
First and Corresponding author: Assistant Prof. Kyung Hee Kim \\ Gaegum-dong 633-165, Busanjin-gu, Busan 614-735 \\ Department of Oral Medicine, Busan Paik Hospital, Inje University \\ Tel: 051-890-6360 \\ E-mail : aussiedent@hotmail.com
}

Received: 2013-07-24

Revised: 2013-08-17

Accepted: 2013-09-02 


\section{INTRODUCTION}

Temporomandibular disorder(TMD)s is a collective term embracing a number of clinical problems that involve the masticatory musculature, the temporomandibular joint(TMJ) and associated structure, or both. ${ }^{1)}$ Temporomandibular disorders have been identified as a major cause of nondental pain in the orofacial region and are considered to be a subclassification of musculoskeletal disorders. ${ }^{2}$ The most frequent presenting symptom is pain usually localized in the muscle of mastication, the preauricular area, and/or the TMJ. In addition to complaints of pain, patients with these disorders frequently have limited or asymmetric mandibular movement and TMJ sounds that are most frequently described as clicking, popping, grating, or crepitus. ${ }^{1)}$

Numerous epidemiologic studies have examined the prevalence of TMDs in given populations. ${ }^{3-11)}$ These studies certainly suggest that signs and symptoms of TMDs are quite common in these populations. In fact, an average of $41 \%$ of these populations reported at least one symptom associated with TMD, while an average of 56\% showed at least one clinical sign. ${ }^{12)}$ According to a recent report of National Health Insurance Cooperation about the statistics of TMDs treatments covered by National health Insurance, the number of TMDs patients treated has been increased by $42.6 \%$ which is the annual average of $9.3 \%$ increase for the last 5 years in Korea (204995 patients in 2008, 292363 patients in 2012). ${ }^{13)}$

Scientific investigation of TMDs first began in the 1950s. ${ }^{12)}$ Since then, there have been many studies about TMD and its epidemiology and this field has gone through a spectacular development. Despite the health professionals' knowledge and information about TMDs have been improved, awareness and understanding of the publics about TMDs seem to be still low. We often meet the patients who don't know what TMDs are and have visited many other hospitals or dental clinics before coming to our hospital. While searching for the reference journals using both national and international searching sites there was only one study ${ }^{14)}$ about general publics' knowledge of TMDs in 2000 and not much else. This research was done to investigate and analyze the dental patients' awareness and understanding about TMDs at this point of time and wanted to use the results of this study in campaigns to raise awareness about TMDs.

\section{ПI. SUBJECTS AND METHODS}

\section{The subjects}

The subjects were the patients who had visited the department of dentistry of Busan Paik Hospital, Inje University or Hanvit dental hospital in Ulsan metropolitan city, right after the approval of Institutional Review Board (IRB number: 13-112) for human research, Inje University, Busan Paik Hospital and were asked to participate in a survey. Among the total number of 243 patients who participated in the survey, the questionnaires of 195 patients who filled in all parts of the questionnaire were used in this study. Under 18 years old patients who might have a difficulty in understanding of the questionnaire and who also needed a parent or guardian to sign a consent form, the patients who refused to participate in and the patients who missed to answer all the questions were excluded.

\section{The methods}

The survey was based on the questionnaire which was used in the previous study ${ }^{14)}$ in year 2000 by Kim and were modified with some more questions. "TMDs" were described as "jaw joint disease" in the questionnaire for the convenience of the dental patients' easy understanding of the questions. For general characteristics, total education period and monthly income categories were added. Since the subjects were the dental patients, the purpose of visit to the department of dentistry or dental hospital was also included. A question about the number of jaw joint symptoms that the subjects had at the time 
of this survey and what they were was also added. In understanding of TMD sections, the questions about cause and treatment method of jaw joint disease were included.

The questionnaire included 6 sections; 1 . General characteristics: gender, age group, education period, monthly income 2. Interest in health issues: general physical health state, frequency of regular physical health examination, source to acquire information on health issue 3. Purpose of visit 4. Awareness of TMD and jaw joint disease: experience of having heard of TMD and jaw joint disease, source of awareness about jaw joint disease 5. Understanding of jaw joint disease : cause, symptoms, treatment, prevention methods 6. Experience of having treated for jaw joint disease. The subjects went through informed consent process and asked to fill in the questionnaire by themselves(Figure 1).

For statistics, categories of general characteristics of the subjects went through a grouping process. Gender was divided into male and female. Age was grouped into three which were 18 to 29 age group, 30 to 49 age group and 50 and over age group. Education period was divided into two groups; under 12 years group and 12 years and over group. Monthly income category was divided into two groups which were under 2 million won group and 2 million won and over group. The purpose of visit to the department of dentistry or dental hospital was grouped into two which were jaw treatment group and other treatment group for convenience of analysis. Subjective symptoms of jaw joint disease of the patients were divided into two groups which were with symptoms group and without symptom group.

The data obtained was statistically analyzed using IBM SPSS Statistics 21.0 with a $\mathrm{p}^{-}$-value of less than 0.05 . Frequency analysis was done for each question. Chi-square test was used to analyze a relationship between TMDs or jaw joint disease awareness and categorical variables and also a relationship between TMDs or jaw joint disease awareness and the purpose of visit. Understanding about the concept of jaw joint disease, source of awareness about jaw joint disease and opinions about where to go for treatment of jaw joint disease were also compared across categorical variables. A relationship between source of awareness about jaw joint disease and the presence of symptoms were also analyzed by chi-square test.

\section{RESULTS}

\section{Awareness of "temporomandibular disorders" and "jaw joint disease" according to gender, age, education period, monthly income and purpose of visit}

The subjects were the total number of 195 . Their gender distribution was $62.1 \%$ female and $37.9 \%$ male. The subjects in 30 to 49 age group(42.1\%) were the most frequently appeared. More than half of the subjects had total education period of 12 years and over(54.9\%) and earned monthly income over 2 million won(51.3\%, Table 1$)$.

The subjects who were aware of the term, "temporomandibular disorders" was $\mathbf{1 7 . 4 \%}$. There was a significant difference in statistics in comparison of TMDs awareness by education period. The group with education period of 12 years and over was more aware of the term, "TMD" than those with under 12 years of education period $(82.4 \%$, $\mathrm{p}<0.01$, Table 1).

The subjects who were aware of the term, "jaw joint disease" were $81.0 \%$. There was a significant difference in statistics in comparison of "jaw joint disease" awareness by age and education period. 30 to 49 age group $(45.6 \%, \mathrm{p}<0.05)$ and the group with education period of 12 years and over $(60.1 \%, \mathrm{p}<0.01)$ were more aware of "jaw joint disease" than other groups (Table 1).

A comparison of awareness of "TMD" and "jaw joint disease" with the purpose of visit to the department of dentistry was analyzed but there was no significant difference in statistics(Table 1). 
Table 1. Awareness of "temporomandibular disorders" and "jaw joint disease" according to gender, age, education period, monthly income and purpose of visit

\begin{tabular}{|c|c|c|c|c|c|c|c|}
\hline \multirow[b]{3}{*}{ Category } & \multirow[b]{3}{*}{$\mathrm{N}(\%)$} & \multicolumn{6}{|c|}{ Awareness of "TMDs" and "Jaw joint disease" N(\%) } \\
\hline & & \multicolumn{3}{|c|}{$\mathrm{TMDs}^{\mathrm{Q} 1}$} & \multicolumn{3}{|c|}{ Jaw joint disease $\mathrm{Q}^{\mathrm{Q}}$} \\
\hline & & Yes & No & $\mathrm{p}$ & Yes & No & $\mathrm{p}$ \\
\hline \multicolumn{8}{|l|}{ Gender } \\
\hline Male & 74(37.9) & $8(23.5)$ & $66(41.0)$ & \multirow{2}{*}{0.057} & $57(36.1)$ & $17(45.9)$ & \multirow{2}{*}{0.265} \\
\hline Female & $121(62.1)$ & $26(76.5)$ & $95(59.0)$ & & 101(63.9) & $20(54.1)$ & \\
\hline \multicolumn{8}{|l|}{ Age(years) } \\
\hline 18-29 & $67(34.3)$ & 14(41.2) & $53(32.9)$ & \multirow{3}{*}{0.372} & $55(34.8)$ & $12(32.4)$ & \multirow{3}{*}{$0.018 *$} \\
\hline $30-49$ & $82(42.1)$ & $15(44.1)$ & $67(41.6)$ & & $72(45.6)$ & $10(27.0)$ & \\
\hline$\geq 50$ & $46(23.6)$ & $5(14.7)$ & $41(25.5)$ & & $31(19.6)$ & $15(40.6)$ & \\
\hline \multicolumn{8}{|c|}{ Education period(years) } \\
\hline$\langle 12$ & $88(45.1)$ & $6(17.6)$ & $82(50.9)$ & \multirow[t]{2}{*}{$0.000 * *$} & $63(39.9)$ & $25(67.6)$ & \multirow[t]{2}{*}{$0.002 * *$} \\
\hline$\geq 12$ & 107(54.9) & $28(82.4)$ & $79(49.1)$ & & $95(60.1)$ & $12(32.4)$ & \\
\hline \multicolumn{8}{|c|}{ Monthly income(10,000 won) } \\
\hline$<200$ & $95(48.7)$ & $14(41.2)$ & $81(50.3)$ & \multirow{2}{*}{0.333} & $76(48.1)$ & $19(51.4)$ & \multirow{2}{*}{0.722} \\
\hline$\geq 200$ & 100(51.3) & $20(58.8)$ & $80(49.7)$ & & $82(51.9)$ & $18(48.6)$ & \\
\hline \multicolumn{8}{|l|}{ Purpose of visit } \\
\hline Jaw treatment & $24(12.3)$ & $4(11.8)$ & 20(12.4) & \multirow{2}{*}{0.916} & 21(13.3) & $3(8.1)$ & \multirow{2}{*}{0.388} \\
\hline Other treatment & $171(87.7)$ & $30(88.2)$ & $141(87.6)$ & & $137(86.7)$ & $34(91.9)$ & \\
\hline Total & $195(100)$ & $34(17.4)$ & $161(82.6)$ & & $158(81.0)$ & $37(19.0)$ & \\
\hline
\end{tabular}

Q1: Have you ever heard of a term "temporomandibular disorders(TMDs)"?

Q2: Have you ever heard of a term "jaw joint disease"?

*: $\mathrm{p}<0.05$ by $\mathrm{x} 2$ test

$* *: \mathrm{p}<0.01$ by $\times 2$ test

2. Understanding about the concept of jaw joint disease according to gender, age, education period and monthly income

To find out the dental patients' understanding about the cause and concept of jaw joint disease, the question "If you have ever heard of the term "jaw joint disease", how do you know about the disease?" was asked to 158 respondents who had heard of the term "jaw joint disease". More than half of the subjects chose overuse of the jaws as the cause and concept of jaw joint disease $(50.6 \%)$. There was no significant difference in statistics in comparison of understanding about the concept of jaw joint disease according to gender, age, education period and monthly income(Table 2).

3. Source of awareness about jaw joint disease according to gender, age, education period, monthly income and presence of symptoms.

Since the question was "If you have ever heard of the term "jaw joint disease", where have you 
Table 2. Understanding about the concept of jaw joint disease according to gender, age, education period and monthly income

\begin{tabular}{|c|c|c|c|c|c|c|}
\hline \multirow[b]{2}{*}{ Category } & \multirow[b]{2}{*}{$\mathrm{N}(\%)$} & \multicolumn{5}{|c|}{ Understanding of "Jaw joint disease" $\mathrm{N3} \mathrm{N}(\%)$} \\
\hline & & $\begin{array}{c}\text { Occlusal } \\
\text { discrepancy }\end{array}$ & $\begin{array}{l}\text { Overuse of } \\
\text { the jaws }\end{array}$ & $\begin{array}{c}\text { Nervous } \\
\text { origin }\end{array}$ & Unknown & $\mathrm{p}$ \\
\hline \multicolumn{7}{|l|}{ Gender } \\
\hline Male & $57(36.1)$ & $9(28.1)$ & $28(35.0)$ & $4(33.3)$ & $16(47.1)$ & \multirow{2}{*}{0.434} \\
\hline Female & 101(63.9) & 23(71.9) & $52(65.0)$ & $8(66.7)$ & $18(52.9)$ & \\
\hline \multicolumn{7}{|c|}{ Age(years) } \\
\hline $18-29$ & $55(34.8)$ & $6(18.8)$ & $33(41.3)$ & $6(50.0)$ & 10(29.4) & \multirow{3}{*}{0.266} \\
\hline $30-49$ & $72(45.6)$ & $17(53.1)$ & $35(43.7)$ & $4(33.3)$ & $16(47.1)$ & \\
\hline$\geq 50$ & $31(19.6)$ & $9(28.1)$ & $12(15.0)$ & $2(16.7)$ & $8(23.5)$ & \\
\hline \multicolumn{7}{|c|}{ Education period(years) } \\
\hline$\langle 12$ & 63(39.9) & $13(40.6)$ & $29(36.2)$ & $5(41.7)$ & $16(47.1)$ & \multirow{2}{*}{0.754} \\
\hline$\geq 12$ & $95(60.1)$ & $19(59.4)$ & $51(63.8)$ & $7(58.3)$ & $18(52.9)$ & \\
\hline \multicolumn{7}{|c|}{ Monthly income(10,000 won) } \\
\hline$\langle 200$ & $76(48.1)$ & $12(37.5)$ & $39(48.7)$ & $6(50.0)$ & 19(55.9) & \multirow{2}{*}{0.513} \\
\hline$\geq 200$ & $82(51.9)$ & 20(62.5) & $41(53.3)$ & $6(50.0)$ & $15(44.1)$ & \\
\hline Total & $158(100)$ & $32(20.3)$ & $80(50.6)$ & $12(7.6)$ & $34(21.5)$ & \\
\hline
\end{tabular}

Q3: If you have ever heard of the term "jaw joint disease", how do you know about the disease?

heard it from?", 158 respondents who were aware of the term, "jaw joint disease" answered to the question. Because it was a multiple response question the total number of responses acquired was 197. TV, radio(41.4\%) was the most frequent source of awareness about jaw joint disease followed by family and friends(20.2\%), hospitals and health professionals(18.2\%), internet(15.7\%) and newspapers, magazines(4.5\%).

The respondents who were aware of the term "jaw joint disease" through TV, radio showed a significant difference in statistics when compared by age groups. 30 to 49 age group was $52.4 \%$ followed by 18 to 29 age group(25.6\%) and 50 and over age group $(22.0 \%, \mathrm{p}<0.05)$.

The respondents who were aware of the term "jaw joint disease" through internet also showed a significant difference in statistics when compared by age groups. 18 to 29 age group was $61.3 \%$ followed by 30 to 49 age group(35.5\%) and 50 and over age group $(3.2 \%, \mathrm{p}<0.001)$.

The respondents who had heard about jaw joint disease from hospitals and health professionals showed a significant difference in statistics when compared by education period groups. The group with education period of 12 years and over was $75 \%$ and the group with education period of less than 12 years was $25 \%(\mathrm{p}<0.05$, Table 3$)$.

To find out where the subjects with jaw joint symptoms had heard about it from, the answers for two questions "Do you have any symptoms which you have chosen in No.9? If you have, please write down what the symptoms are." and "If you have ever heard of the term "jaw joint disease", where have you heard it from?" were compared.

The total respondents were 158 out of 195 
Table 3. Source of awareness about jaw joint disease according to gender, age, education period, monthly income and presence of symptoms

\begin{tabular}{|c|c|c|c|c|c|c|c|c|c|c|c|}
\hline & & & & jource of awar & areness & s about ". & Jaw joint & $t$ disease" ${ }^{Q 4}$ & ${ }^{4}$ respo & onse(\%) & \\
\hline Category & $\begin{array}{l}\text { response } \\
\quad(\%)\end{array}$ & $\begin{array}{c}\mathrm{TV} \\
\text { radio }\end{array}$ & $\mathrm{p}$ & $\begin{array}{l}\text { Newspapers, } \\
\text { magazines } \neq\end{array}$ & $\mathrm{p}$ & Internet & $\mathrm{p}$ & $\begin{array}{l}\text { Family \& } \\
\text { friends } \neq\end{array}$ & $\mathrm{p}$ & $\begin{array}{c}\text { Hospitals } \\
\& \text { health } \\
\text { professionals } \neq\end{array}$ & $\mathrm{p}$ \\
\hline Gender & & & & & & & & & & & \\
\hline Male & $71((36.0)$ & $33(40.2)$ & O 257 & $4(44.4)$ & 0590 & $11(35.5)$ & 0930 & $10(25.6)$ & O & 13(36.1) & 0996 \\
\hline Female & $126(64.0)$ & 49(59.8) & 0.251 & $5(55.6)$ & 0.090 & $20(64.5)$ & 0.939 & $29(74.4)$ & 0.110 & 23(63.9) & 0.990 \\
\hline Age(years & & & & & & & & & & & \\
\hline $18-29$ & $76(38.6)$ & $21(25.6)$ & & 3(33.3) & & 19(61.3) & & $18(46.2)$ & & 15(41.7) & \\
\hline $30-49$ & $83(42.1)$ & $43(52.4)$ & $0.041 *$ & 3(33.3) & 0.539 & 11(35.5) & $0.001 * *$ & 13(33.3) & 0.162 & 13(36.1) & 0.426 \\
\hline$\geq 50$ & 38(19.3) & $18(22.0)$ & & 3(33.3) & & $1(3.2)$ & & $8(20.5)$ & & $8(22.2)$ & \\
\hline $\begin{array}{l}\text { Education } \\
\text { period(yea }\end{array}$ & & & & & & & & & & & \\
\hline$<12$ & $75(38.1)$ & $34(41.5)$ & 0672 & $4(44.4)$ & 0773 & 12(38.7) & 0882 & $16(41.0)$ & 0866 & $9(25.0)$ & $0.038 *$ \\
\hline$\geq 12$ & $122(61.9)$ & $48(58.5)$ & 0.018 & $5(55.6)$ & 0.171 & 19(61.3) & 0.000 & 23(59.0) & 0.000 & $27(75.0)$ & \\
\hline $\begin{array}{l}\text { Monthly i } \\
(10,000 \mathrm{wc}\end{array}$ & & & & & & & & & & & \\
\hline$<200$ & $91(46.2)$ & $35(42.7)$ & 0.157 & $4(44.4)$ & 0.821 & $17(54.8)$ & 0.402 & 19(48.7) & 0.929 & $16(44.4)$ & 0.617 \\
\hline$\geq 200$ & $106(53.8)$ & $47(57.3)$ & & $5(55.6)$ & & $14(45.2)$ & & 20(51.3) & & $20(55.6)$ & \\
\hline $\begin{array}{l}\text { Presence } \\
\text { symptoms }\end{array}$ & & & & & & & & & & & \\
\hline No & $115(58.4)$ & $56(68.3)$ & $0.029 *$ & $8(88.9)$ & 0.070 & $15(48.4)$ & 0.1136 & 24(61.5) & 0.836 & 12(33.3) & $0.000 * *$ \\
\hline Yes & $82(41.6)$ & 26(31.7) & & 1(11.1) & & 16(51.6) & & 15(38.5) & & $24(66.7)$ & \\
\hline Total & 197(100) & $82(41.4)$ & & $9(4.5)$ & & $31(15.7)$ & & $39(20.2)$ & & $36(18.2)$ & \\
\hline
\end{tabular}

Q4: If you have ever heard of the term "jaw joint disease", where have you heard it from? (multiple responses were allowed)

$*: \mathrm{p}<0.05$ by $\mathrm{x} 2$ test

$* *: \mathrm{p}<0.01$ by $\mathrm{x} 2$ test

\#: Result of multiple response analysis

subjects. The question asking for the source of awareness about jaw joint disease was a multiple response question therefore the subjects were allowed to answer multiple responses hence total numbers were 197. The respondents who didn't have subjective symptoms of jaw joint disease were aware of jaw joint disease through $\mathrm{TV}$, radio(68.3\%, $\mathrm{p}<0.05)$ while respondents who had symptoms acquired information from hospitals and health professionals $(66.7 \%, 0<0.01)$. 
Table 4. Where to go for treatment of jaw joint disease according to gender, age, education period and monthly income

\begin{tabular}{|c|c|c|c|c|c|c|c|c|c|}
\hline \multirow[b]{2}{*}{ Category } & \multirow[b]{2}{*}{$\mathrm{N}(\%)$} & \multicolumn{8}{|c|}{ Where to go for treatment of jaw joint disease ${ }^{Q 5} \mathrm{~N}(\%)$} \\
\hline & & $\begin{array}{l}\text { Chinese } \\
\text { medicine } \\
\text { clinic }\end{array}$ & $\begin{array}{c}\text { Dept. Of } \\
\text { orthopedic } \\
\text { surgery }\end{array}$ & $\begin{array}{l}\text { Dept. of } \\
\text { neurosur } \\
\text { gery }\end{array}$ & $\begin{array}{l}\text { Dept. } \\
\text { of } \\
\text { ENT }\end{array}$ & $\begin{array}{l}\text { Dept. of } \\
\text { dentistry }\end{array}$ & Others & $\begin{array}{l}\text { Don't } \\
\text { know }\end{array}$ & $\mathrm{p}$ \\
\hline \multicolumn{10}{|l|}{ Gender } \\
\hline Male & $74(37.9)$ & $0(0.0)$ & $13(48.1)$ & $0(0.0)$ & $2(66.7)$ & $53(34.6)$ & $1(50.0)$ & $5(62.5)$ & \multirow{2}{*}{0.489} \\
\hline Female & $121(62.1)$ & $1(100.0)$ & $14(51.9)$ & $1(100.0)$ & 1(33.3) & $100(65.4)$ & $1(50.0)$ & $3(37.5)$ & \\
\hline \multicolumn{10}{|c|}{ Age(years) } \\
\hline $18-29$ & 67(34.4) & $0(0.0)$ & 7(25.9) & $0(0.0)$ & 1(33.3) & $55(36.0)$ & $1(50.0)$ & $3(37.5)$ & \multirow{3}{*}{0.770} \\
\hline $30-49$ & $82(42.0)$ & $0(0.0)$ & $15(55.6)$ & $1(100.0)$ & 1(33.3) & $60(39.2)$ & $1(50.0)$ & $4(50.0)$ & \\
\hline$\geq 50$ & $46(23.6)$ & $1(100.0)$ & $5(18.5)$ & $0(0.0)$ & 1(33.3) & $38(24.8)$ & $0(0.0)$ & 1(12.5) & \\
\hline \multicolumn{10}{|c|}{$\begin{array}{l}\text { Education } \\
\text { period(years) }\end{array}$} \\
\hline$<12$ & $88(45.1)$ & $0(0.0)$ & $16(59.3)$ & $0(0.0)$ & $2(66.7)$ & $65(42.5)$ & $2(100)$ & $3(37.5)$ & \multirow{2}{*}{0.382} \\
\hline$\geq 12$ & 107(54.9) & $1(100.0)$ & $11(40.7)$ & $1(100.0)$ & $1(33.3)$ & $88(57.5)$ & $0(0.0)$ & $5(62.5)$ & \\
\hline \multicolumn{10}{|c|}{$\begin{array}{l}\text { Monthly income } \\
\text { (10,000 won) }\end{array}$} \\
\hline$\langle 200$ & $95(48.7)$ & $0(0.0)$ & $14(51.9)$ & $0(0.0)$ & 1(33.3) & $75(49.0)$ & $1(50.0)$ & $4(50.0)$ & \multirow{2}{*}{0.471} \\
\hline$\geq 200$ & $100(51.3)$ & $1(100.0)$ & $13(48.1)$ & $1(100.0)$ & 2(66.6) & $78(60.0)$ & $1(50.0)$ & $4(50.0)$ & \\
\hline Total & $195(100)$ & $1(0.5)$ & $27(13.8)$ & $1(0.5)$ & 3(1.5) & $153(78.5)$ & $2(1.0)$ & $8(4.1)$ & \\
\hline
\end{tabular}

Q5: Where do you think you have to visit firstly for the treatment of "jaw joint disease"?

4. Where to go for treatment of jaw joint disease according to gender, age, education period and monthly income

$78.5 \%$ of the subjects chose department of dentistry as the first place to visit for treatment of jaw joint disease. $13.8 \%$ chose department of orthopedic surgery and $4.1 \%$ of the subjects didn't know where to go. The subjects who chose department of ENT were $1.5 \%$ followed by others $(1 \%)$, Chinese medicine clinic and department of neurosurgery $(0.5 \%$ respectively). There was no significant difference in statistics according to gender, age, education period and monthly income (Table 4).
5. Understanding about sign and symptoms, causes, treatment and prevention methods of jaw joint disease

Since the questions asked about sign and symptoms, causes, treatment and prevention methods of jaw joint disease were multiple responses questions the total numbers of responses obtained were vary by category. Noise during mouth opening and closing (26.9\%) was the most frequently responded sign and symptoms of jaw joint disease, followed by mouth opening difficulty(25.1\%), pain on the area in front of ears(13.7\%) in sequence. Enjoying hard food chewing(19.5\%) was the most frequently answered for the causes of jaw joint 
Table 5. Understanding about sign and symptoms, causes, treatment and prevention methods of jaw joint disease

\begin{tabular}{|c|c|}
\hline Sign and symptoms & $\%$ \\
\hline noise during mouth opening and closing & 26.9 \\
\hline Mouth opening difficulty & 25.1 \\
\hline Pain on the area in front of ears & 13.7 \\
\hline Facial asymmetry & 13.4 \\
\hline Headache & 8.2 \\
\hline Noise in ears & 6.6 \\
\hline Neck and shoulder pain & 6.1 \\
\hline Causes & $\%$ \\
\hline Enjoying hard food chewing & 19.5 \\
\hline Occlusal discrepancy & 19.0 \\
\hline Chewing with one side only & 18.5 \\
\hline Teeth grinding, clenching & 16.3 \\
\hline Trauma (direct trauma on facial area) & 11.8 \\
\hline Stress & 11.0 \\
\hline Anxiety, depression, tension & 3.9 \\
\hline Treatment methods & $\%$ \\
\hline Jaw joint surgery & 28.0 \\
\hline Intraoral appliance therapy & 23.9 \\
\hline Physical therapy & 14.6 \\
\hline Medication & 13.9 \\
\hline Habit control & 13.4 \\
\hline Botox treatment & 3.2 \\
\hline Spinal therapy & 3.0 \\
\hline Prevention methods & $\%$ \\
\hline Avoid eating hard food & 22.1 \\
\hline Avoid opening mouth wide & 17.0 \\
\hline Chewing food with both side of molars simutaneously & 15.4 \\
\hline Maintain a right position of head and shoulder & 11.9 \\
\hline Avoid chewing gum frequently & 11.5 \\
\hline Avoid any stressful conditions & 10.5 \\
\hline Using mouthpiece for severe exercise & 6.6 \\
\hline Keep brushing teeth after meal & 4.0 \\
\hline Avoid eating sweet things frequently & 1.0 \\
\hline Total & 100 \\
\hline
\end{tabular}




\section{Questionnaire}

\begin{tabular}{ll|}
\hline Sex: $\square$ male & $\square$ female \\
Age: ( & \\
Education period: & \\
$\square 12$ years and over & $\square$ under 12 years \\
Monthly income (in 10,000 won): \\
$\square$ under $200 \quad \square 200$ and over \\
\hline
\end{tabular}

1. How is your physical health in general?

$\square$ good

$\square$ fair

$\square$ poor

2. How often do you visit your doctor for a regular physical health examination?

$\square$ once a year or more

$\square$ once in a few years

口never

3. How do you normally get information on health issues?

(multiple responses are allowed)

$\square T V$, radio

口newspapers, magazines

$\square$ internet

$\square$ family \& friends

$\square$ hospitals $\&$ health professionals

4. What is your purpose of visit to the department of dentistry/dental hospital? $\square$ tooth treatment

$\square$ gum treatment

$\square$ prosthetic treatment(gold crown, denture, implant)

$\square$ orthodontic treatment

$\square$ jaw treatment

$\square$ surgical treatment(includes extraction of third molar)

$\square$ oral examination

5. Have you ever heard of a term "temporomandibular disorders"?

$\square$ yes

口no

6. Have you ever heard of a term "jaw joint disease"?

口yes

$\square$ no (go to number 9)

7. If you have ever heard of the term "jaw joint disease", where have you heard it from? (multiple responses are allowed)

$\square T V$, radio

$\square$ newspapers, magazines

$\square$ internet

$\square$ family \& friends

$\square$ hospitals \& health professionals

8. If you have ever heard of the term "jaw joint disease", how do you know about the disease?

$\square$ It is a disease caused by occlusal discrepancy

$\square$ It is a disease caused by overuse of the jaws

$\square$ It is a disease caused by nervous origin

$\square$ I don't know

9. Choose item/items which you think as symptoms associated with "jaw joint disease"? (multiple responses are allowed)

$\square$ Pain on the area in front of ears

$\square$ mouth opening difficulty

\section{$\square$ headache}

$\square$ noise in ears

$\square$ noise during mouth opening \& closing

$\square$ facial asymmetry

$\square$ neck and shoulder pain

10. Do you have any symptoms which you have chosen in No.9? If you have, please write down what the symptoms are.

$\square$ No symptoms

$\square 1$ symptom

$\square 2$ symptoms

$\square 3$ symptoms

$\square 4$ symptoms \& more

11. Choose item/items which you think as causes of "jaw joint disease". (multiple responses are allowed)

$\square$ trauma (direct trauma on facial area)

$\square$ enjoying hard food chewing

$\square$ occlusal discrepancy

$\square$ Teeth grinding, clenching

$\square$ stress

$\square$ chewing with one side only

$\square$ anxiety, depression, tension

12. Where do you think you have to visit firstly for the treatment of "jaw joint disease"?

$\square$ Chinese medicine clinic

$\square$ Dept. of orthopedic surgery

$\square$ Dept. of neurosurgery

$\square$ Dept. of ENT

$\square$ Dept. of dentistry

$\square$ others!

$\square$ I don't know

13. Have you ever visited any of places below for the treatment of "jaw joint disease"? (multiple responses are allowed)

$\square$ Chinese medicine clinic

$\square$ Dept. of orthopedic surgery

$\square$ Dept. of neurosurgery

$\square$ Dept. of ENT

$\square$ Dept. of dentistry

$\square$ others!

$\square$ I don't know

14. Choose item/items which you think that is required for the treatment of "jaw joint disease". (multiple responses are allowed)

$\square$ Jaw joint surgery

$\square$ Medication

$\square$ Spinal therapy

$\square$ Physical therapy

$\square$ Intraoral appliance therapy

$\square$ Habit control

$\square$ Botox treatment

15. Choose item/items which you think that is required for the prevention of "jaw joint disease". (multiple responses are allowed)

$\square$ Avoid opening mouth widely

$\square$ Avoid eating hard food

$\square$ Avoid eating sweet things frequently

$\square$ Chewing food with both side of molars simultaneously

$\square$ Avoid any stressful conditions

$\square$ Keep brushing teeth after meal

$\square$ Avoid chewing gum frequently

$\square$ Maintain a right position of head \& shoulder

$\square$ Using mouthpiece for severe exercise

Fig. 1. Form and contents of questionnaire 
disease, followed by occlusal discrepancy $(19.0 \%)$ and chewing with one side only(18.5\%). TMJ surgery(28\%) was the most frequently responded treatment method for jaw joint disease, followed by intraoral appliance therapy(23.9\%) and physical therapy $(14.6 \%)$ in sequence. There were some respondents(3\%) who chose "spinal therapy" which was an inadequate method of TMD treatment even though the percentage was still low. Avoid eating hard food(21.1\%) was the most frequently responded preventive method for jaw joint disease, followed by avoid opening mouth wide(17.0\%) and chewing food with both sides of molars simultaneously(15.4\%). There were some respondents who chose "keep brushing teeth after meal" and "avoid eating sweet things frequently" which were not related to the prevention methods of jaw joint disease, even though the percentage was still low $(4.0 \%$ and $1.0 \%$ respectively).

\section{DISCUSSION}

The definition of "awareness" from Wikipedia is the state or ability to perceive, to feel, or to be conscious of events, objects, or sensory patterns. In this level of consciousness, sense data can be confirmed by an observer without necessarily implying understanding. More broadly, it is the state or quality of being aware of something. Therefore the questions asking about the experience of having heard of the term, "TMDs" and "jaw joint disease" were interpreted as the awareness of the term, "TMDs" and "jaw joint disease". The subjects who were aware of the term, "TMDs" was $17.4 \%$ and the subjects who were aware of the term, "jaw joint disease" were $81.0 \%$. This result was similar to the previous study by $\mathrm{Kim}^{14)}$ that the general public was more familiar with the term of "jaw joint disease"(52.24\%) rather than "TMDs"(10.68\%). "TMDs" was a medical term that people didn't know what that was by hearing the name only without any explanation. Therefore the term, "jaw joint disease" should be used in general to explain about the disease to the patients or to the publics.
The group with education period of 12 years and over was about 4 times more aware of the term "TMDs" $(82.4 \%)$ than those with under 12 years of education group and the group with education period of 12 years and over was about 1.5 times more aware of the term, "jaw joint disease"(60.1\%) than those with under 12 years of education group. This indicated that the higher the level of education of the patient, the more aware the patient was of the disease. The study by Ok et at $\mathrm{al}^{15)}$ wanted to find out whether the patients' understanding about TMD could affect initial treatment of TMD based on a questionnaire score. The result was similar to ours that those who were in Jr. college or had higher scholarship showed higher understanding than those with final graduation of high school or had lower scholarship. 30 to 49 age group was more aware of the term, "jaw joint disease (45.6\%) than any other age groups. Epidemiologic studies reveal that the most TMD symptoms are reported by people in the 20 - to 40- years age group. ${ }^{16-18)}$ The reason for 30 to 49 age group in our study were more aware of jaw joint disease might be that they could have the most TMD symptoms in this period of time than any other age groups. It was also the period of time that middle-aged people started to have interest in their health state and to have a regular physical health examination. A comparison of awareness of "TMD" and "jaw joint disease" with the purpose of visit to the department of dentistry or dental hospital were analyzed but there was no significant difference in statistics. One out of every four patients in a general population would report some awareness of TMD symptoms, yet less than $10 \%$ of the population studied felt that their problem was severe enough to call for treatment. ${ }^{12)}$ The numbers of patients who visited the department of dentistry or dental hospital for jaw joint treatment were $12.3 \%$ in our study.

The subjects who were aware of term, "jaw joint disease" were also asked to answer about the concept of the disease therefore wanted to know whether those patients went beyond a state of having just awareness about the disease but also had some knowledge about the disease and it was 
interpreted as understanding. Even though there wasn't any significant difference in statistics in comparison of understanding about the concept of jaw joint disease according to gender, age, education period and monthly income, more than half of the subjects who were aware of "jaw joint disease", answered overuse of the jaws as the cause and concept of jaw joint disease(50.6\%). However the percentage of the subjects who were aware of the term "jaw joint disease" but didn't really know about the disease was also quite high as $21.5 \%$. Therefore thorough but clear and easy explanation about the disease should be provided to the patients and to the publics.

Among the source of awareness about "jaw joint disease" TV and radio(41.4\%) was the most frequent source followed by family and friends (20.2\%), hospitals and health professionals(18.2\%), internet $(15.7 \%)$ and newspapers, magazines (4.5\%). The result of the previous study by $\mathrm{Kim}^{14)}$ showed that TV and radio(40.36\%) was also the most frequent route through which people have heard about jaw joint disease followed by other people who already heard of jaw joint disease (25.05\%), hospitals and health professionals(16.58\%), newspapers and magazines $(15.86 \%)$ and internet $(2.16 \%)$ in sequence and Kim predicted that there would be an increase in numbers of people who had heard about jaw joint disease through internet in the future. 13 years after our study showed a similar result but the use of internet increased remarkably. Among the respondents who had heard about jaw joint disease through $\mathrm{TV}$ and radio, more than half of the respondents fell into 30 to 49 age group $(52.4 \%)$. Among the respondents who were aware of jaw joint disease through internet, 18 to 29 age group showed the highest percentage of $61.3 \%$. Among the respondents who had heard about jaw joint disease from hospitals and health professionals, the group with education period of 12 years and over showed $75 \%$ which was 3 times higher than the percentage of the group with lower education period. From these results, the author thought of customized campaign for each age group that could raise public awareness of TMDs much more effectively for example, public awareness campaign about TMDs on the internet targeting younger generation and TV campaign for middle- aged group. Nowadays, internet is the most fast and easy way to get information about what we want to know. However it is hard to get an accurate information about the disease from vast amounts of information which are a mixture of excessive advertising writings and subjective thoughts. Hence an official web counseling center for TMDs leading by Korean Academy of Orofacial pain and Oral medicine where people can trust may also be a good idea to provide accurate information about TMDs to the publics. A comparison between presence of subjective symptoms of jaw joint disease and source to awareness about "jaw joint disease" was done and the result was obvious that the respondents who didn't have subjective symptoms of jaw joint disease were aware of jaw joint disease through TV, radio(67.9\%) while respondents who had symptoms acquired information through hospitals and health professionals $(66.7 \%)$.

The opinions about where to go for treatment of jaw joint disease were analyzed and $78.5 \%$ of the subjects chose department of dentistry as the first place to visit for treatment of jaw joint disease. $13.8 \%$ chose department of orthopedic surgery and $4.1 \%$ of the subjects didn't know where to go. The subjects who chose department of ENT were 1.5\% followed by others(1\%), Chinese medicine clinic and department of neurosurgery (0.5\% respectively). The previous study by $\mathrm{Kim}^{14)}$ showed a different result from our study that in answer to the question who is the eligible person to treat jaw joint disease, $35.26 \%$ answered the dentists are and $41.99 \%$, orthopedicians. The difference in the results might be caused by that the subjects in our study were the patients who had visited the department of dentistry or dental hospital while the previous study was based on the general public.

Frequency analysis was done to learn about the dental patients' understanding about the sign and symptoms, causes, treatment and prevention 
methods of jaw joint disease. Noise during mouth opening and closing (26.9\%) was the most frequently responded sign and symptoms of jaw joint disease, followed by mouth opening difficulty(25.1\%), pain on the area in front of ears $(13.7 \%)$ in sequence. Enjoying hard food chewing(19.5\%) was the most frequently answered for the causes of jaw joint disease, followed by occlusal discrepancy $(19.0 \%)$ and chewing with one side only(18.5\%). Avoid eating hard food(21.1\%) was the most frequently responded preventive method for jaw joint disease, followed by avoid opening mouth wide(17.0\%) and chewing food with both sides of molars sequentially $(15.4 \%)$. These results showed that the dental patients understood quite well about the sign, symptoms, causes and prevention methods of TMDs. TMJ surgery(28\%) was the most frequently responded method of treatment for jaw joint disease, followed by occlusal appliance therapy(23.9\%) and physical therapy $(14.6 \%)$. The majority of patients suffering with TMD achieved good relief of symptoms with conservative therapy. ${ }^{19-22)}$ Longterm follow-up of TMD patients showed that 50\% to $>90 \%$ of the patients had few or no symptoms after conservative treatment. ${ }^{1)}$ If the TMJ persistent pain was associated with specific structural changes in the joint structure, surgical intervention could be considered with caution by an oral and maxillofacial surgeon. This was suggested only after comprehensive non-surgical rehabilitation care had not been successful. ${ }^{23)}$ Therefore we needed to emphasize more about conservative methods for TMD treatment in both public awareness campaign and explanation to the dental patients.

Because this study was conducted in a small sample of the patients presenting to the department of dentistry of Busan Paik Hospital, Inje University or Hanvit dental hospital in Ulsan metropolitan city they were not necessarily representative of broader populations. Therefore more studies in depth with broader populations should be continued in near future.

\section{CONCLUSIONS}

This study was conducted to investigate and analyze the dental patients' awareness and understanding about TMDs. Among the total number of 243 patients who had visited the department of dentistry of Busan Paik Hospital, Inje University or Hanvit dental hospital in Ulsan metropolitan city and participated in the survey, 195 patients who filled in all parts of the questionnaire were selected as the subjects. The results were as follows.

1. The subjects who were aware of the term, "temporomandibular disorders" were $17.4 \%$. The group with education period of 12 years and over was significantly more aware of the term " TMDs" (82.4\%) than those with under 12 years of education period group. The subjects who were aware of the term, "jaw joint disease" were $81.0 \%$. 30 to 40 age group (45.6\%) was the most significantly aware of the term "jaw joint disease" than those with other age groups and the group with education period of 12 years and over(60.1\%) was significantly more aware of the term "jaw joint disease" than those with under 12 years of education group.

2. More than half of the subjects chose overuse of the jaws as the cause and concept of jaw joint disease $(50.6 \%)$. There was no significant difference in statistics in comparison of understanding about the concept of jaw joint disease according to gender, age, education period and monthly income.

3. TV, radio(41.4\%) was the most frequent source of awareness about jaw joint disease followed by family and friends(20.2\%), hospitals and health professionals(18.2\%), internet(15.7\%) and newspapers, magazines(4.5\%). 30 to 49 age group showed the most significantly high percentage (52.4\%) in statistics among the respondents who were aware of jaw joint disease through TV, radio. 18 to 29 age group showed the most significantly high percentage(61.3\%) in statistics among the respondents who were aware of jaw 
joint disease through internet. The respondents' group with education period of 12 years and over showed significantly higher percentage $(75 \%)$ in statistics among the respondents who were aware of jaw joint disease from hospitals and health professionals. The respondents who didn't have subjective symptoms of jaw joint disease were aware of jaw joint disease through TV, radio $(67.9 \%, \mathrm{p}<0.05)$ while the respondents who had symptoms acquired information through hospitals and health professionals $(66.7 \%, 0<0.01)$.

4. $78.5 \%$ of the subjects chose department of dentistry as the first place to visit for treatment of jaw joint disease. 13.8\% chose department of orthopedic surgery and $4.1 \%$ of the subjects didn't know where to go. The subjects who chose department of ENT were 1.5\% followed by others $(1 \%)$, Chinese medicine clinic and department of neurosurgery ( $0.5 \%$ respectively).

5. Noise during mouth opening and closing(26.9\%) was the most frequently responded sign and symptoms of jaw joint disease, followed by mouth opening difficulty(25.1\%), pain on the area in front of ears $(13.7 \%)$ in sequence. Enjoying hard food chewing(19.5\%) was the most frequently answered the causes of jaw joint disease, followed by occlusal discrepancy (19.0\%) and chewing with one side only(18.5\%). TMJ surgery $(28 \%)$ was the most frequently responded treatment method for jaw joint disease, followed by occlusal appliance therapy(23.9\%) and physical therapy(14.6\%) in sequence. Avoid eating hard food $(21.1 \%)$ was the most frequently responded preventive method for jaw joint disease, followed by avoid opening mouth wide(17.0\%) and simultaneous using of molar of both side when chewing food(15.4\%) in sequence.

\section{ACKNOWLEDGEMENTS}

The author acknowledges Associate Professor, SH Jeong from Department of Oral Medicine, School of Dentistry, Pusan National University for her useful advice and consistent encouragement and
Assistant professor, SH Jeong from Dept. of Preventive \& Community Dentistry, School of Dentistry, Pusan National University for his help in data analysis.

\section{REFERENCE}

1. The American Academy of Orofacial Pain, edited by Okeson JP. Orofacial pain: guidelines for assessment, diagnosis, and management. Illinois, 1996, Quintessence Publishing Co, Inc, pp. 116, 142.

2. Okeson JP. Bell's Orofacial Pains. $5^{\mathrm{TH}}$ ed., Chicago, 1995, Quintessence Publishing Co, Inc, pp. 123-133.

3. Solberg WK, Woo MW, Houston JB. Prevalence of mandibular dysfunction in young adults. J Am Dent Assoc 1979;98(1):25-34.

4. Ingervall B, Mohlin B, Thilander B. Prevalence of symptoms of functional disturbances of the masticatory system in Swedish men. J Oral Rehabil 1980;7(3):185-197.

5. Rieder CE, Martinoff JT, Wilcox SA. The prevalence of mandibular dysfunction. Part I: Sex and age distribution of related signs and symptoms. J Prosthet Dent 1983;50(1):81-88.

6. Gazit E, Lieberman M, Eini R, et al. Prevalence of mandibular dysfunction in 10-18 year old Israeli schoolchildren. J Oral Rehabil 1984;11(4):307-317.

7. Pullinger AG, Seligman DA, Solberg WK. Temporomandibular disorders. Part II: Occlusal factors associated with temporomandibular joint tenderness and dysfunction. J Prosthet Dent 1988;59(3):363-367.

8. Agerberg G, Inkapool I. Craniomandibular disorders in an urban Swedish population. J Craniomandib Disord 1990;4(3):154-164.

9. Magnusson T, Carlsson GE, Eagermark I. Changes in subjective symptoms of craniomandibular disorders in children and adolescents during a 10-year period. J Orofac Pain 1993;7(1):76-82.

10. Tanne K, Tanaka E, Sakuda M. Association between malocclusion and temporomandibular disorders in orthodontic patients before treatment. J Orofac Pain 1993;7(2):156-162.

11. Hiltunen K, Schmidt-Kaunisaho K, Nevalainen J, et al. Prevalence of signs of temporomandibular disorders among elderly inhabitants of Helsinki, Finland. Acta Odontol Scand 1995;53(1):20-23.

12. Okeson JP. Management of temporomandibular disorders and occlusion. 7th ed., Missouri, 2013, 
Elservier Mosby, pp. 102-107.

13. National Health Insurance Service: http://www.nhis.or. $\mathrm{kr} /$ portal/site/main/MENU_WBDCC01

14. Kim SH. Study of general public's knowledge of TMD: how predominantly is TMD understood by people. J KAOM 2000;25(4):371-382.

15. Ok SJ, Suh BJ, Tae IH, Ko MY, Ahn YW. The effects of established-knowledge of temporomandibular disorders on initial treatment. J KAOM 2008;33(1):75-83.

16. Von KM, Dworkin SF, le RL, Kruger A. An epidemiologic comparison of pain complaints, Pain 1988;32(2):173-183

17. Dworkin SF, LeResche L, Von KMR. Diagnostic studies of temporomandibular disorders:challenges from an epidemiologic perspective. Anesth Prog 1990;37(2-3):147-154

18. De Kanter RJ, Truin GJ, Burgersdijk RC, ET AL. Prevalence in the Dutch adult population and a meta-analysis of signs and symptoms of temporomandibular disorders. J Den Res 1993;72(11):1509 -1518 .
19. Carlsson GE. Long-term effects of treatment of craniomandibular disorders. J Craniomand Pract 1985; 3:337-342.

20. Randolph CS, Greene CS, Moretti R, et al. Conservative management of temporomandibular disorders: A posttreatment comparison between patients from a university clinic and from private practice. Am J Orthod Dentofac Orthop 1990;98; 77-82.

21. Skeppar J, Nilner M. T reatment of craniomandibular disorders in children and young adults. J Orofac Pain 1993;7:362-369.

22. Brown DT, Gaudet EL. Outcome measurement for treated and untreated TMD patients using the TMJ scale. J Craniomand Pract 1994;12:216-221.

23. Lund JP, Lavigne GJ, Dubner R, Sessle BJ. Orofacial pain: from basic science to clinical management. Illinois, 2001, Quintessence Publishing Co, Inc, pp. 245. 
국문초록

측두하악장애에 대한 치과 내원환자의 인지도와 이해도에 관한 설문조사 연구

김경희

인제대학교 부산백병원 구강내과

본 연구는 측두하악장애에 대한 치과 내원환자의 인지도와 이해도를 조사, 분석하기 위해 시행되었다. 인제대학교 부산백병 원 치과 혹은 울산광역시 소재 한빛치과병원을 방문한 총 243 명의 환자에게 설문조사를 시행하였고, 설문지의 모든 문항에 대해 성실히 답한 195 명을 대상으로 하여 다음과 같은 결과를 얻었다.

1. "측두하악장애"란 용어를 인지하고 있는 환자는 전체 대상자의 $17.4 \%$ 였고, 총 12 년 이상의 학력을 가진 군 $(82.4 \%, \mathrm{p}<0.01)$ 은 다른 군에서 보다 “측두하악장애”에 대한 인지도가 유의하게 높았다. “턱관절질환”이란 용어를 인지하고 있는 환자는 전체 대상자의 $81.0 \%$ 였고, 30-49세 연령군(45.6\%, $\mathrm{p}<0.05)$ 과 총 12 년 이상의 학력을 가진 군 $(60.1 \%, \mathrm{p}<0.01)$ 에서 다른 군보다 "턱관절질환"이란 용어에 대한 인지도가 유의하게 높았다.

2. 전체의 과반수 이상인 $50.6 \%$ 가 턱관절질환의 개념으로 “턱을 무리하게 사용해서 생기는 병이다"를 선택했다.

3. 턱관절질환에 대해 들은 경로로TV, 라디오(41.4\%)가 가장 많았고, 가족과 친구(20.2\%), 병원 및 병원관계자(18.2\%), 인터넷 (15.7\%) 및 신문과 잡지(4.5\%)순이었다. $\mathrm{TV}$, 라디오를 통해서 턱관절질환에 대해 들어본 응답자 중 30-49세 연령군이 다른 군보다 유의하게 높은 비율 $(52.4 \%, \mathrm{p}<0.05)$ 을 보였다. 인터넷을 통해서 턱관절질환에 대해 들어본 응답자 중 18-29세 연령군 이 다른 군보다 유의하게 높은 비율 $(61.3 \%, \mathrm{p}<0.01)$ 을 보였다. 병원과 병원관계자를 통해서 턱관절질환에 대해 들어본 응답 자 중 총 12 년 이상의 학력을 가진 군 $(75 \%, \mathrm{p}<0.05)$ 이 다른 군보다 유의하게 높은 비율을 보였다.

4. 환자들은 입을 벌리고 다물 때 턱에서 나는 소리(26.9\%), 입을 크게 벌리지 못한다(25.1\%), 귀 앞쪽 부위의 통증(13.7\%)을 턱관절질환의 증상과 징후로 골랐다. 턱관절질환의 원인으로는 딱딱하거나 질긴 음식을 즐겨먹기 $(19.5 \%)$, 아래, 윗니가 잘 안 맞물림(19.0\%), 한쪽 어금니로 음식씹기(18.5\%)를 많이 선택했다. 턱관절질환의 치료법으로 턱관절수술(28\%)을 가장 많이 꼽았고, 구강내 장치치료(23.9\%), 물리치료(14.6\%)가 그 뒤를 따랐다. 턱관절질환의 예방법으로 딱딱한 음식의 섭취를 줄인다(21.1\%), 입을 너무 크게 벌리지 않는다(17.0\%), 양쪽 어금니로 음식을 씹는다(15.4\%)를 많이 선택했다.

주제어: 설문지, 이해도, 인지도, 측두하악장애, 턱관절질환 